\title{
The Analysis of Household Food Security Level in Jelobo Village, Klaten Regency, Central Java
}

\author{
Mohamad Tegar Baharudin ${ }^{1, *}$ Juhadi $^{2,}$ Heri Tjahjono $^{3,}$ Ariyani Indrayati ${ }^{4}$ \\ ${ }^{1.2 .3 .4}$ Geography Department, Faculty of Social Science, Universitas Negeri Semarang \\ Corresponding e-mail: mohamadtegar20@students.unnes.ac.id
}

\begin{abstract}
The purpose of this research is to find out the level of food security in each hamlet in Jelobo Village and analyze the factors influence household food security. The population in this research was the entire land area of $251.71 \mathrm{Ha}$ and the population of Jelobo Village which amount to 4,405 people with a total of 1,440 households. The sample in this research was agricultural land and family heads in Jelobo Village which were taken by using simple random sampling technique. The number of heads of households sampled was 93 households and divided into 3 hamlets. The data collection techniques used were field observation, interviews, and documentation. The field data was taken and analyzed by using quantitative descriptive techniques. The results of the analysis of household food security in Jelobo Village show that Ngrodon Hamlet has 6,45\% of respondents resistant to food, $77,41 \%$ of respondents are quite resistant, and 16,13\% of respondents are not food resistant. The Wantilan sub-village has 3,22\% of respondents resistant to food, $74,19 \%$ of respondesnts are quite resistant, and $22,58 \%$ of respondents cannot stand food. Then, Jelobo Hamlet has 3,22\% of respondents are resistant to food, $61,29 \%$ of respondent are quite resistant and $35,48 \%$ of respondents are not food resistant.
\end{abstract}

Keywords: food security, household, food stability.

\section{INTRODUCTION}

According to The Constitutional Law of Indonesia No. 18 of 2012 of concerning food, Food security is a condition for the fulfillment of food needs in a country down to individuals, which is reflected in the availability of food that is sufficient, in quantity and quality, safe, diverse, nutritious, equitable and affordable and appropriate and not in conflict with the religion, belief and culture of the community, in order to be able to provide a healthy, active, productive life in a sustainable manner. The concept of food security is used at the household level as the measurement of welfare and is carried out to conceptually operate $n$ the design, implementation, evaluation of government programs and policies. Households have a good level of food security if they have the ability to obtain and access food needed by family members to meet their daily needs [6]. The definition of food security is based on four interrelated components, as follows: (1) availability of food is seen from its physical presence in a certain country or region; (2) food accessibility which is reflected based on the ability to obtain food from own production or through purchasing; (3) utilization, or the ability to obtain benefits from food based on food safety and personal health; and (4) stability of access that is free from shocks or food consumption cycles [5]. Food security is multidimensional in nature which requires comprehensive measures involving various indicators, which are combined to produce a composite value of food security [3]. Food security is a multi-dimensional concept, which requires the assessment and measurement of various indicators which can combine various dimensions in together [4].

\section{METHODS}

This research was conducted in Jelobo Village, Wonosari District, Klaten Regency. Jelobo Village is a 
village which located in the lowlands with an altitude of \pm 109 meters above sea level with an area of 251.71 $\mathrm{Ha} / 2.51 \mathrm{Km}^{2}$. Data collection techniques that used in this study were field observation techniques, interviews, and documentation. Field data was taken and analyzed by using quantitative descriptive techniques to analyze the components of food security indicators.

\begin{tabular}{lll}
\hline No & $\begin{array}{l}\text { Resistance } \\
\text { Category }\end{array}$ & \multicolumn{1}{c}{ Size } \\
\hline 1. & Food Resistant & $\begin{array}{l}\text { All elements are fulfilled } \\
\text { (stable enough, good } \\
\text { access, expenditure >50\% } \\
\text { for non-food) } \\
\text { 1-2 elements are not } \\
\text { fulfilled } \\
\text { 3-4 elements are not } \\
\text { fulfilled }\end{array}$ \\
3. & $\begin{array}{l}\text { Resistant Food } \\
\text { Not Resistant }\end{array}$ & \multicolumn{2}{c}{} \\
\hline
\end{tabular}

Source: Adam (2008) adapted from LIPI (2004).

\section{RESULT AND DISSCUSIONS 3.1. Adequacy of Food Availability}

Adequacy of food availability is known by doing 24 Hours Food Recall to analyze energy and nutrients based on the data from the recall of daily food consumption (24 hours) by comparing energy and nutrient adequacy (RDA) figures [10]. Data from interviews, then performed a computerized analysis by using the Nutrisurvey 2007 application to determine the nutritional content and calories in food. Based on data analysis conducted in 3 hamlets in Jelobo village, it is known that Ngrodon and Wantilan sub-villages have a good level of food availability, with $80,64 \%$ of respondents in Ngrodon and 87,09\% respondents in Wantilan having $>70 \%$ RDA $(2,100 \mathrm{kcal} /$ capita/day $)$ and having $19,35 \%$ of respondents unable to meet minimum energy requirement of $\leq 70 \%$ $(2,100 / \mathrm{kcal} / \mathrm{capita} /$ day $)$. Then, Jelobo Hamlet has a sufficient level of poor food availability, with $58,06 \%$ of respondents having> $70 \%$ RDA $\quad(2,100$ $\mathrm{kcal} / \mathrm{capita} /$ day) and having $41,93 \%$ of respondents unable to meet the minimum energy needs. Factors that influence the adequacy of household food availability are combinations and variations of side dishes in meeting daily nutritional needs.

\section{Ngrodon Hamlet}

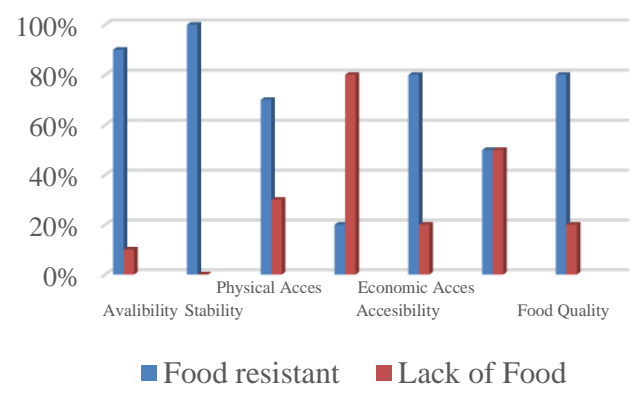

Figure 1. Graphic of Food Security Indicators in Ngrodon Hamlet (Source: primary data, 2020).

\subsection{Food Availability and Stability}

The stability of food availability is based on the daily feeding frequency of family members. The standard in food availability is if the daily food frequency of family members is at least 3 times, if the frequency of food is less than 3 times the family has not been able to meet the daily food availability. Food availability is based on physical food availability through national food availability and commercial food in the community, the production of agricultural products, plantations, and household food reserves [8]. Based on the data obtained, the majority of $96,77 \%$ of the population in Ngrodon hamlets are able to meet daily food needs 3 times. Then, population in Wantilan 93,54\% and population in Jelobo 90,32\% are able to meet the daily food needs. However, there are still $9,67 \% \%$ of respondents in Jelobo Hamlet who have a frequency of eating 2 times a day.

\subsection{Food Accessibility}

Food accessibility at the household level is seen from the ease with which households obtain food, as measured by physical access and economic access. Physical access is based on the distance and ease of access between markets and food vendors and ownership of agricultural land. Then economic access is based on the level of household income each month and the percentage of food expenditure in meeting daily needs. Ngrodon sub-village has physical access based on market distance, has $61,29 \%$ of respondents who have easy access to markets and 38,70\% of respondents who have a market distance of $>3 \mathrm{~km}$. In access to ownership of agricultural land, 9,67\% of respondents in Ngrodon Hamlet have cultivated agricultural land and 90,32\% of respondents who do not have agricultural land. The level of household 
income each month in Ngrodon Hamlet, 67,75\% of respondents have sufficient income levels and 32,25\% of respondents have below average income. Then, the percentage of food expenditure in meeting daily needs, $41,93 \%$ of respondents have a level of food expenditure $<50 \%$ of total household expenditure.

The Wantilan sub-village has physical access based on the market distance, has $87,09 \%$ of respondents who have easy access to markets and $12,90 \%$ of respondents who have a market distance of $>3 \mathrm{~km}$. In agricultural land ownership in Wantilan Hamlet there are $3,22 \%$ of respondents who own agricultural land and $96,77 \%$ of respondents do not have agricultural land. The level of household income in Wantilan Hamlet, 58,06\% of respondents have sufficient income levels and $41,93 \%$ of respondents have below the average income level flat. Percentage of food expenditure in Wantilan Hamlet $32,25 \%$ of respondents have food expenditure $<50 \%$ of total household expenditure and $67,74 \%$ of respondents have expenditure $>50 \%$ of total expenditure.

Jelobo sub-village has physical access based on market distance, has $96,77 \%$ of respondents that have easy access to markets with a distance of $<3 \mathrm{~km}$ and $3,23 \%$ of respondents who have a market distance of $>$ $3 \mathrm{~km}$. In terms of agricultural land ownership, 9,67\% of respondents have cultivated agricultural land $90,32 \%$ of respondents in Jelobo Hamlet do not have cultivated agricultural land. The level of income of the people in Jelobo sub-village has $58,06 \%$ above average income and $41,93 \%$ below average. Then in the percentage of food expenditure, $29,03 \%$ of respondents have food expenditure $<50 \%$ of total expenditure and the other $70,96 \%$ of respondents have food expenditure above $50 \%$ of total household expenditure.

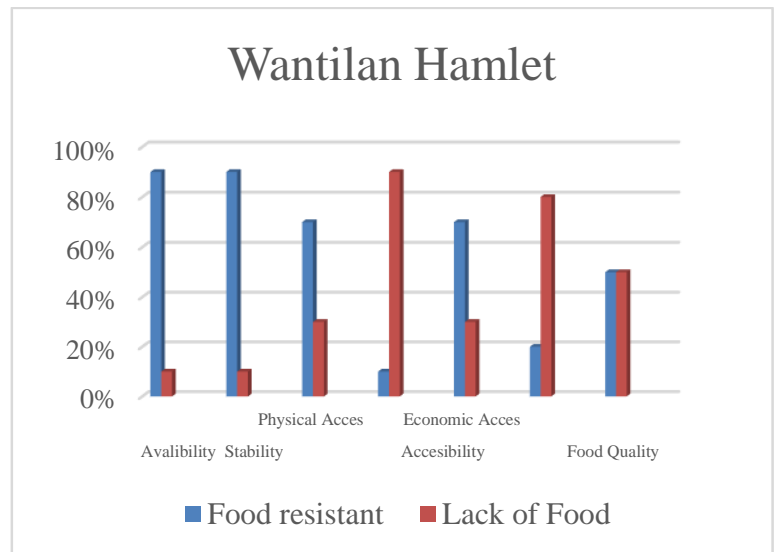

Figure 2. Graphic of Food Security Indicators in Wantilan Hamlet (Source: primary data, 2020).

\subsection{Food Quality and Safety}

The quality / safety of the type of food consumed to fulfill the nutritional needs is carried out by involving various types of food with different nutritional content, so that the measure of food safety is only seen from the presence or absence of foodstuffs containing animal and / or vegetable protein consumed at houshold. Measurement of food quality is seen based on data on daily food expenditures (side dishes) in the level of consumption that contains animal and / or vegetable protein. Food quality indicates that there is nutrition needed by the body while food quantity indicates the amount of nutrients in a food. Ngrodon sub-village has 70,96\% of respondents who are able to fulfill the animal protein adequacy rate $\geq 70 \%$ (57 grams / capita / day) and another $29,03 \%$ have not been able to fulfill the animal adequacy rate. Then Wantilan Hamlet has a percentage of $70,96 \%$ of respondents who are able to fulfill the animal protein adequacy rate and another $29,03 \%$ have not been able to fulfill. Jelobo Hamlet has the smallest percentage, $41,93 \%$ of respondents are able to fulfill their animal protein needs, while the other $58,06 \%$ have not been able to fulfill the daily needs of animal protein.

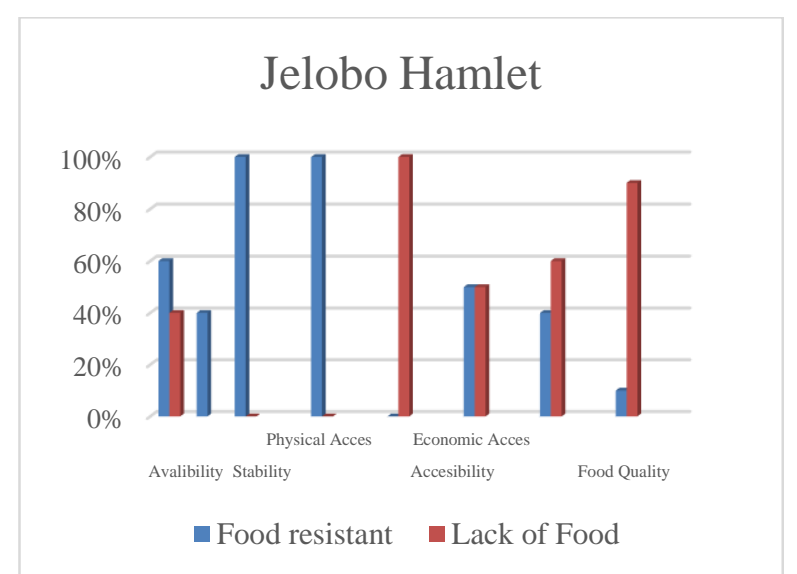

Figure 3. Graphic of Food Security Indicators in Jelobo Hamlet (Source: primary data, 2020).

\subsection{Classification of Household Food Security Levels}

Composite results from 4 components, as follows: sufficiency of food availability, stability of food availability, accessibility / affordability of food, and food quality / safety are known that 3 hamlets in Jelobo village have different characteristics. Ngrodon Hamlet has $6,45 \%$ of respondents resistant to food, $77,41 \%$ of respondents are quite resistant, and $16,13 \%$ of respondents are not food resistant. The Wantilan 
sub-village has $3,22 \%$ of respondents resistant to food, $74,19 \%$ of respondesnts are quite resistant, and $22,58 \%$ of respondents cannot stand food. Then, Jelobo Hamlet has 3,22\% of respondents are resistant to food, $61,29 \%$ of respondent are quite resistant and $35,48 \%$ of respondents are not food resistant. In accumulation, Jelobo Village has a level of food security at a fairly resistant level even though there are people who cannot stand food security in each of their hamlets.

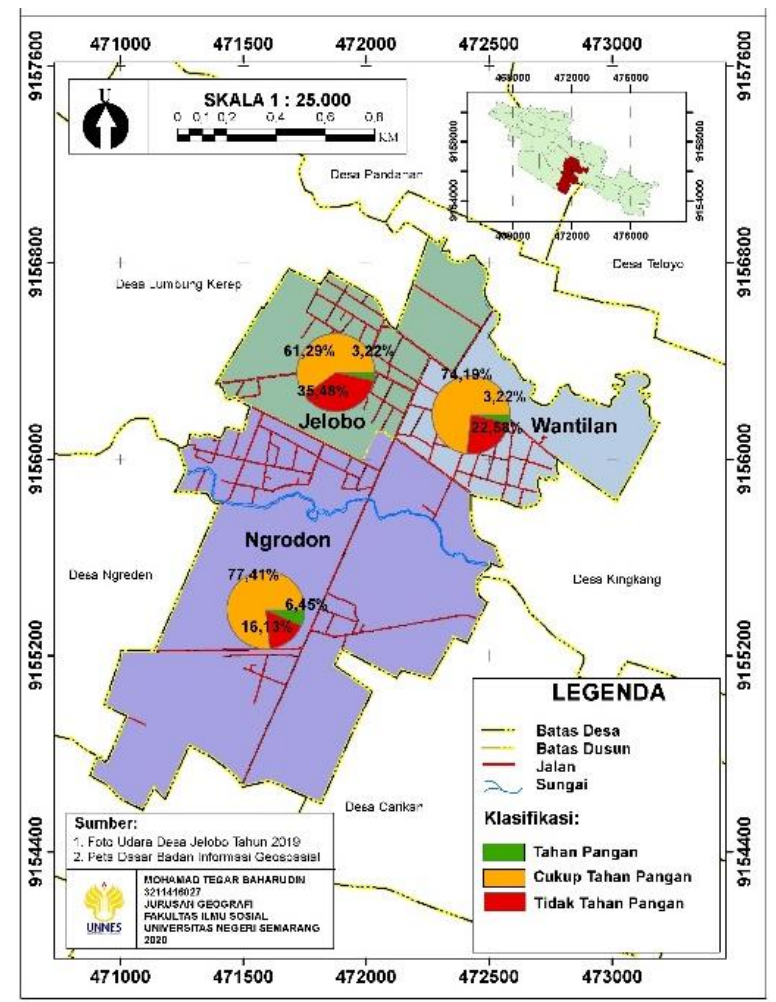

Figure 4. Map of Household Food Security in Jelobo Village.

\section{CONCLUSION}

Each hamlet in Jelobo Village has different characteristics based on the physical and social conditions of the community. The level of food security in Jelobo Village is at a sufficient level of food security, although there are still some households that are at a level of food insecurity. This condition reflects each hamlet which represent the situation of household food in areas that have the potential to develop agricultural land. The strategy carried out in an effort to improve food security in Jelobo Village is through intensification and variation in household food consumption types and increasing new economic sectors to empower people to be able to access food more affordable.

\section{REFERENCES}

[1] Adam, Felecia P. 2008. Ketahanan Pangan Rumah Tangga di Wilayah Pulau Kecil (Studi Kasus di Kabupaten Maluku Tenggara Barat). Tesis. Yogyakarta: Universitas Gadjah Mada.

[2] Badan Ketahanan Pangan, Kementerian Pertanian. 2018. Indeks Ketahanan Pangan Indonesia 2018. Jakarta: Badan Ketahanan Pangan, Kementerian Pertanian.

[3] Barrett, Christopher.B., 2010. Measuring food insecurity. Journal Science. Vol. 327. pp. 825828. doi: $10.1126 /$ science. 1182768 .

[4] Carletto, Calogero, Alberto Zezza \& Raka Banerjee. 2013. Towards better measurement of household food security: Harmonizing indicators and the role of household surveys. Journal Global Food Security 2. Vol.2. pp. 30- 40.

[5] Pinstrup-Andersen, P. (2009) 'Food security: definition and measurement', Food Security, 1(1), pp. 5-7. doi: 10.1007/s12571-008-000.

[6] PPK-LIPI.

2004."Ketahanan

Pangan,Kemiskinan dan Demografi Rumah Tangga”. Seri Penelitian PPK-LIPI No. 56/2004. Jakarta: Puslit Kependudukan LIPI.

[7] Renzaho, Andre.M.N, dan David Mellor. 2010. Food security measurement in cultural pluralism: Missing the point or conceptual misunderstanding?.Journal Nutrition. Vol. 26 (1). pp. 1-9. Doi: 10.1016/j.nut.2009.05.001.

[8] Republic of Indonesia. 2012. Undang-Undang No. 18 Tahun 2012 Tentang Pangan. Jakarta: Sekretariat Negara.

[9] Sirajuddin, Surmita, dan Trina Astuti. 2018. Bahan Ajar Gizi Survey Konsumsi Pangan. Jakarta: Pusat Pendidikan Sumber Daya Manusia Kesehatan Kementerian Kesehatan Republik Indonesia 